J. Clin. Chem. Clin. Biochem.

Vol. 26, 1988, pp. $659-666$

(C) 1988 Walter de Gruyter \& Co.

Berlin - New York

\title{
Human Nesidioblastosis Tissue as an Immunogen for Generation of Islet Cell Specific Monoclonal Antibodies
}

\author{
By K.-D. Gerbitz, B. Boenke, A. Paprotta, U. Chemnitz \\ Institut für Klinische Chemie und Forschergruppe Diabetes, Städt. Krankenhaus München-Schwabing and
}

\section{G. Hübner}

Institut für Pathologie, Universität München

(Received March 10/August 8, 1988)

Summary: Nesidioblastosis pancreas was used as an immunogen in BALB/c-mice to generate monoclonal antibodies against structures of human islet cells. Seven clones were selected by screening 311 growing hybridomas for reactivity with the rat insulinoma cell line, RIN m5F, and with cryostat sections from human pancreas. None of the selected clones reacted with pancreatic hormones or endocrine-specific peptides. Monoclonal antibodies cross-reacting with the RIN-cell line also bound to different endocrine organs or cell lines, while some RIN-cell-negative clones bound only to Langerhans islets from human pancreas.

\section{Introduction}

The different endocrine cells of human pancreatic islets of Langerhans serve highly spezialized functions, such as specific hormone production and secretion. Furthermore, specific structural elements also seem to be expressed, at least on the surface of insulin secreting B-cells. In conjunction with HLA class II antigens these differentiation antigens might serve as specific targets for a T-cell response during the autoimmune pathogenesis of type I diabetes. Due to the limited availability of the respective target cell, i.e. the human B-cell, on the one hand and of the natural autoantibodies on the other hand, research on the immunopathogenesis of type I diabetes is rendered difficult and therefore little is known about the nature of the respective cell surface antigens. One way to approach this problem is the use of monoclonal antibodies directed against defined antigenic sites of the islet cells. Here we describe the development of a panel of murine monoclonal antibodies against human islets of Langerhans derived from nesidioblastosis tissue. Their cross-reactivity with other endocrine tissues or cells is characterized, and some preliminary data on the biochemical nature of the respective antigens are presented.

\section{Materials and Methods \\ Preparation of the immunogen}

Nesidioblastosis tissue was obtained after total pancreatectomy of a one year old female child suffering from severe hypoglycaemic attacks. Indirect immunofluorescence using islet cell antibody-positive diabetic sera and an anti-insulin serum from guinea pig revealed an increased number of intact encapsulated islets as well as dispersed single islet cells. The fraction used as an immunogen in mice was prepared in two different ways. In the first procedure, tissue $(100 \mathrm{mg})$ was homogenized (Potter homogenizer) in ice cold phosphate buffered saline, and the homogenate centrifuged at $100000 \mathrm{~g}$; the pellet fraction was resuspended in phosphate buffered saline and used as immunogen. It was stored at $-80^{\circ} \mathrm{C}$ before use. In parallel, the nesidioblastosis tissue was subjected to collagenase treatment according to 1.c. (1). Isolated islets were picked up under a stereomicroscope and transferred to tissue culture ( 24 well Costar plates) in RPMI 1640 medium containing $20 \%$ foetal calf serum. During two weeks in primary culture the intact encapsuled islets disrupted and formed a monolayer of C-peptideand proinsulin-secreting epitheloid like cells. After 4 weeks in culture the cells were harvested, lysed by freezing and thawing and centrifuged at $20000 \mathrm{~g}$ for 20 minutes in the cold. The supernatant containing the soluble cytoplasmic material was discarded, and the pellet fraction used as immunogen.

\section{Generation of monoclonal antibodies}

BALB/c mice (4-6 weeks old) were immunized either with the pellet fraction from homogenized nesidioblastosis tissue or by the membrane fraction from cultured cells. About $10 \mathrm{mg}$ of protein was injected intraperitoneally four times every three 
weeks. Four days after the last injection the animals were sacrificed and the spleen cells were harvested and washed three times in cell culture medium containing $L$-glutamine, sodium pyruvate, and penicillin/streptomycin but no foetal calf serum. Spleen cells $\left(2.2 \times 10^{7}\right)$ were fused with the nonsecretor murine myeloma cell line NSO $\left(3.5 \times 10^{8}\right.$ cells $)(2)$ using polyethylene glycol according to the original procedure (3) with slight modifications. Hypoxanthine, aminopterine, thymidin (HAT) selection medium was added two days after initial culture in 24 well Costar plates $\left(2.5 \times 10^{5}\right.$ cells/ml RPMI 1640 containing $20 \%$ foetal calf serum). Five days later surviving cells could be identified for the first time under the microscope. At this time the medium was changed twice every week or whenever necessary. Two weeks after fusion, the foetal calf serum content was reduced from 20 to $10 \%$. Growing hybridomas were doubled and the cell culture supernatant was tested for the presence of interesting antibodies. Hybridomas producing antibodies which reacted with islets were cloned by plating 3000-300000 cells per $\mathrm{ml}$ in $0.3 \%$ soft agar containing $20 \%$ foetal calf serum and picking up with glass capillaries 10 days later.

\section{Electron microscopy}

For electron microscopy cultured cells were harvested and fixed in glutaraldehyde $(6.25 \%)$, postrixed in $2 \%$ buffered osmic acid solution for 2 hours, and embedded in Epon. Semithin sections were stained in Azur-II-Methylene blue solution (4). Ultrathin sections were contrasted with uranyl acetate and lead citrate.

\section{Screening for antibody production of the hybridoma}

Antibody production of the hybrids was screened by an ELISA using the rat insulinoma cell line (RINm5F) (5) as well as by indirect immunofluorescence on cryostat sections from human pancreas of a blood group 0 donor. Briefly, the procedure of the ELISA was as follows: about 100 RINm5F cells per well seeded in microplate wells formed a monolayer after two to three days in culture. After careful washing with phosphate buffered saline the cells were fixed by incubation with $0.5 \%$ glutaraldehyde for 15 minutes at room temperature, again washed three times with phosphate buffered saline, then incubated in phosphate buffered saline containing $150 \mathrm{mmol} / \mathrm{l}$ glycine for 15 minutes. After a further wash the cells were stored in the cold and could be used within the next four to five days. Before testing the cell culture supernatants, fixed cells were washed three times with phosphate buffered saline containing $0.05 \%$ Tween 20 . Cell culture supernatant $(0.1 \mathrm{ml})$ was then added and incubated for at least one hour at room temperature. After washing three times with phosphate buffered salineTween, $0.1 \mathrm{ml}$ of peroxidase-conjugated antimouse immunoglobulin (Sigma) in a dilution of $1: 1000$ were added and incubated for one hour. After extensive washing with phosphate buffered saline-Tween the enzymic reaction was initiated by addition of $0.1 \mathrm{ml}$ of $5.5 \mathrm{mmol} o$-phenylene diamine in 100 $\mathrm{mmol} / \mathrm{l}$ citrate buffer, $\mathrm{pH}$ 5.0. Absorbance was measured in a Dynatech Microplate Reader MR 600 at $405 \mathrm{~nm}$ after a fixed time of 30 minutes. Absorbance values for controls (medium) were found between 0.01 and 0.02 , while the values for positive, i.e. antibody-containing cell supernatants ranged from $0.05-$ 1.5.

In parallel, hybrids were screened for reactivity with human islets using an indirect immunofluorescence assay with FITCconjugated antimouse immunoglobulin (Sigma) diluted $1: 30$ in phosphate buffered saline on cryostat sections of human pancreas from a blood group 0 donor. For identification of Langerhans islets as well as for direct comparison with the clones to be tested, the following islet cell positive "probes" were used:

1. a mouse monoclonal antibody BISL-32 (6) generated against bovine islets, but cross-reacting with human islets. This antibody was directly labelled with tetramethyl rhodamine isothio- cyanate and used in a double fluorescence procedure by combining the direct immunofluorescence with tetramethyl rhodamine isothiocyanate labelled BISL-32 with the indirect procedure using the clone to be tested and the FITC-labelled antimouse immunoglobulin as second antibody.

2. an islet cell antibody positive diabetic serum in an indirect double fluorescence procedure using tetramethyl rhodamine isothiocyanate labelled antihuman IgG as well as FITC labelled antimouse immunoglobulin as second antibodies, respectively

3. a polyclonal antiserum developed against human insulin in guinea pig in an indirect double fluorescence procedure, using a tetramethyl rhodamine isothiocyanate-conjugated anti guinea pig immunoglobulin and FITC-conjugated antimouse immunoglobulin as the second antibodies, respectively.

\section{Binding assays}

Possible reactivity of the selected monoclonal antibodies with some islet cell-specific polypeptides, such as human proinsulin, insulin, C-peptide, glucagon and somatostatin was investigated in the following way: trace amounts of the respective ${ }^{125} \mathrm{I}$ iodinated islet cell-specific polypeptides (about $10^{4}$ counts/min $\times 0.2 \mathrm{ml}$ ) were incubated with the monoclonal antibody to be tested for 18 hours at $4^{\circ} \mathrm{C}$. Following incubation, $0.05 \mathrm{ml}$ of human $\gamma$-globulin and immediately thereafter a solution of 0.25 $\mathrm{ml}$ polyethylene glycol (PEG-6000) $(25 \%)$ was added to achieve complete precipitation of the antibodies. Samples were centrifuged, the pellets were washed twice with polyethylene glycol solution, then counted for radioactivity. Binding was expressed as percentage of total radioactivity added.

\section{Western immunoblotting technique}

Nesidioblastosis pancreas (case 3) was first homogenized and solubilized in $1 \%$ NP40 buffer. After high speed centrifugation $(20000 \mathrm{~g})$ the detergent extracts were resolved in $1 \%$ sodium dodecylsulphate-polyacrylamide gel electrophoresis (SDSPAGE) on a gradient gel from 6-16\%. Proteins were blotted onto nitrocellulose paper using a semidry blot apparatus (Biometra, Göttingen) at a constant current of $5 \mathrm{~mA} / \mathrm{cm}^{2}$ for 30 minutes. After incubation for 60 minutes with the monoclonal antibody to be tested (diluted tenfold) the corresponding protein antigen bands were identified by indirect immunostaining using biotinylated antimouse immunoglobulin and streptavidin biotinylated alkaline phosphatase complex (Amersham) with 5bromo-4-chloro-3-indolylphosphate as substrate and nitroblue tetrazolium salt.

\section{Results}

Figure 1 shows the formation of a monolayer of epitheloid like cells from an isolated nesidioblastosis islet after 10 days in primary culture. During this time C-peptide secretion into the culture medium increased slowly but continuously (data not shown). After four weeks in culture the cells were harvested by removing $\mathrm{Ca}^{2+}$ from the medium using $2 \mathrm{mmol} / \mathrm{l}$ EDTA in phosphate buffered saline. Electron microscopy revealed mostly endocrine cells with typical dense granula as demonstrated in figure 2. About $50 \%$ were Bcells, $40 \% \mathrm{~A}$-cells and the rest could not be identified exactly. 


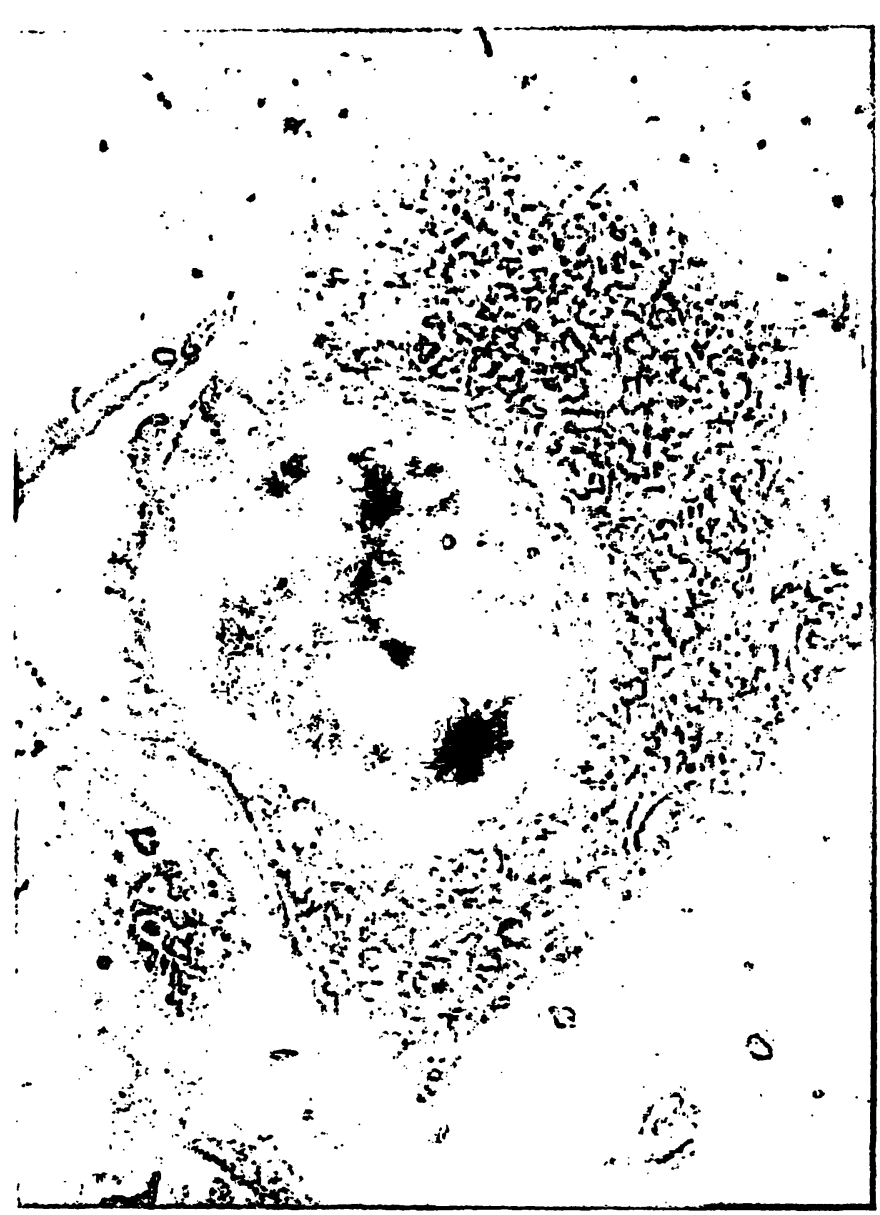

Fig. 1. Human islet isolated from nesidioblastosis pancreas after 14 days in culture; formation of a monolayer. Magnification: $\times 100$

Fusion of murine spleen cells immunized by islet cell membrane fractions with the murine myeloma cell line NSO resulted in 311 growing hybridomas from a total of 1296 microtitre wells. The screening of the hybrids for antibody production was first performed using the RIN-cell ELISA. However, some hybrids, reactive in the RIN-ELISA, did not react on cryostat sections from human pancreas, and conversely some reacting on cryostat sections were negative in the RIN-ELISA. Thus it was also necessary to test all the hybrids for reactivity on cryostat sections from human pancreas. Table 1 shows the results obtained with both methods. 24 hybridoma secreted antibodies were reacting only in the RIN-cell ELISA, 34 hybrids reacted in both asșay systems, while 42 hybrids were positive only on pancreatic cryostat sections. From the latter two groups 7 clones were selected by comparison with the fluorescence pattern of islet cell antibody-positive diabetic sera, a polyclonal anti-insulin serum from guinea pig and the mouse monoclonal antibovine islet antibody BISL-32.

The islet cell antibody-positive diabetic sera used for comparison did not react with certain defined cells within the islets but gave a diffuse staining of the
Tab. 1. Reactivity of hybridoma supernatants within different systems

\begin{tabular}{|c|c|c|c|}
\hline \multirow{2}{*}{$\begin{array}{l}\text { All } \\
\text { hybrids }\end{array}$} & \multicolumn{3}{|l|}{ Reactive with } \\
\hline & $\begin{array}{l}\text { RIN-ELISA } \\
\text { positive } \\
\text { Cryostate } \\
\text { section negative }\end{array}$ & $\begin{array}{l}\text { Cryostat sec- } \\
\text { tion positive } \\
\text { RIN-ELISA } \\
\text { negative }\end{array}$ & $\begin{array}{l}\text { positive in } \\
\text { both systems }\end{array}$ \\
\hline 311 & 24 & 42 & 34 \\
\hline
\end{tabular}

whole islets. The same is true for the monoclonal antibody BISL-32. However, cell staining with this antibody was more clear and more related to certain cell types of the islets. Staining of B-cells was possible with the polyclonal anti-insulin serum from guinea pig. Examples for comparison with islet cell-specific probes are given in the figures $3 \mathrm{a}-\mathrm{e}$ and $4 \mathrm{a}-\mathrm{e}$. Some monoclonal antibodies, for example MAB 1163 B1, stained similar structures of the islet architecture as did the MAB BISL-32 (fig. $3 \mathrm{a}$ and $4 \mathrm{a}$ ). Preincubation of the cryostat sections with excess amounts of purified monoclonal antibodies followed by incubation with BISL-32, however, showed that binding of BISL32 was unaffected by any of the monoclonals used for preincubation. Thus, certain monoclonal antibodies demonstrated a similar fluorescence pattern to that

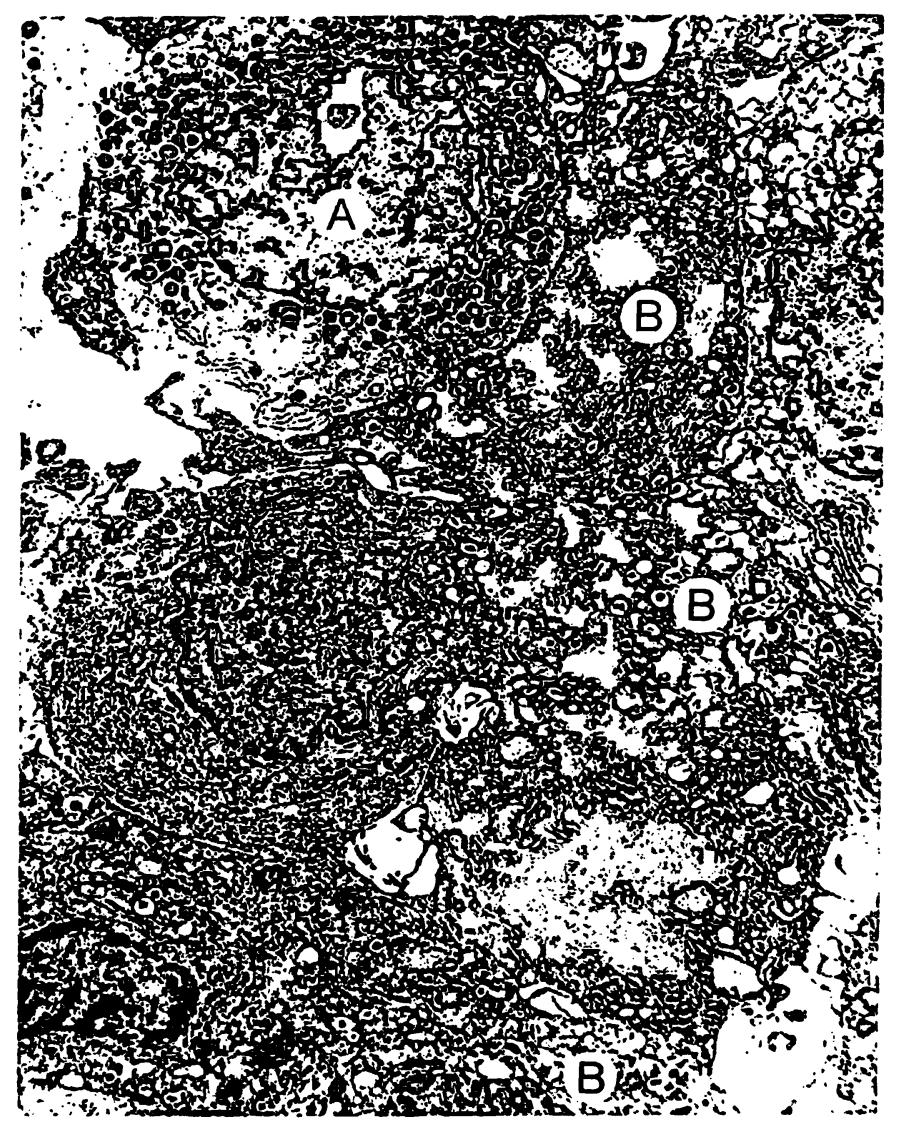

Fig. 2. Electron micrograph of islet cells maintained in culture for four weeks. A, A-cells; B, B-cells (magnification: $\times 5000$ ) 

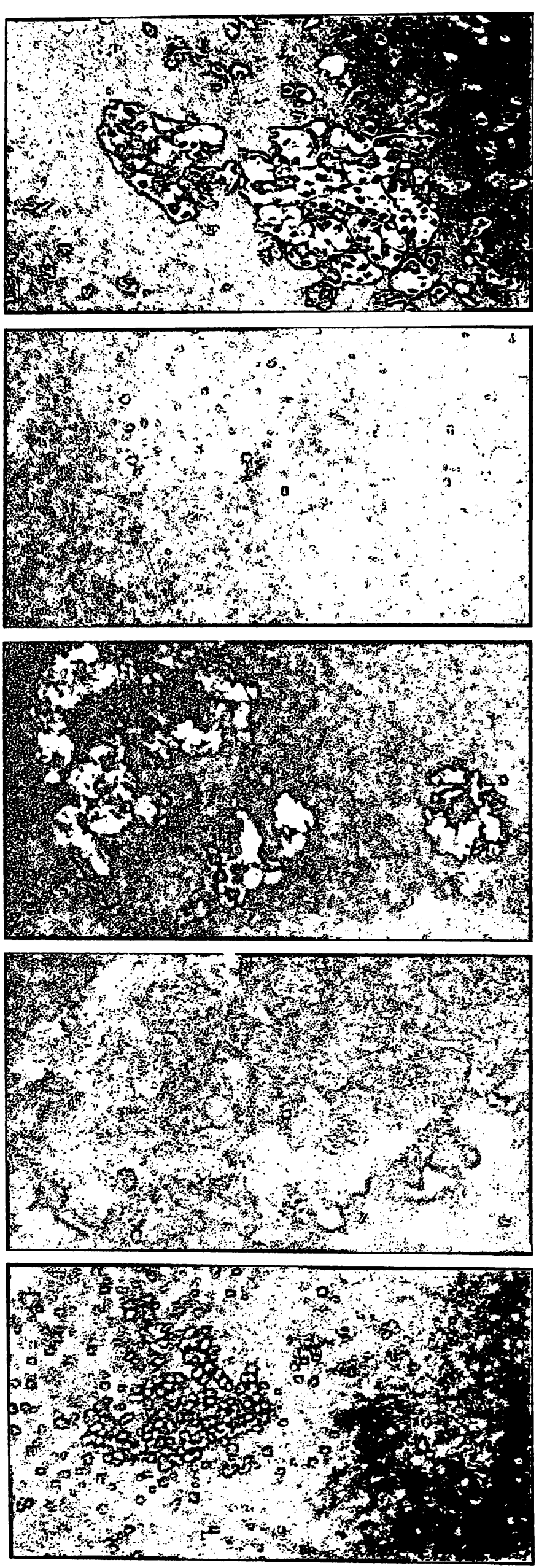

Fig. 3. a

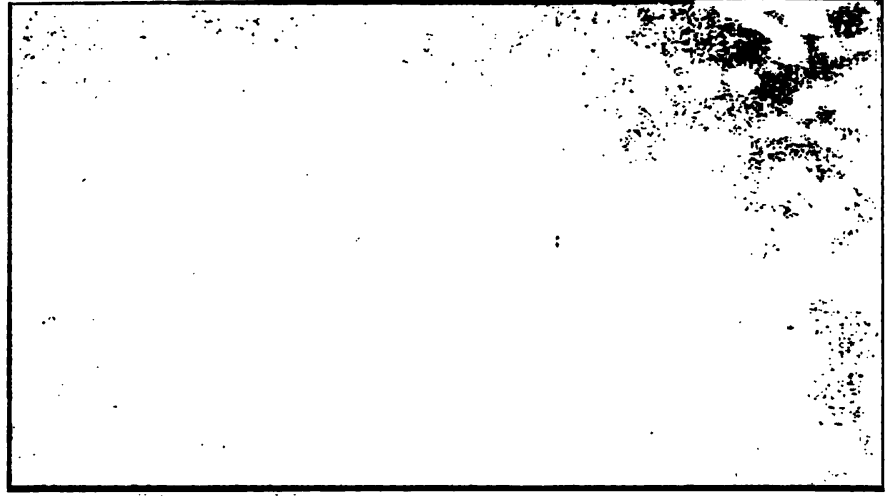

b

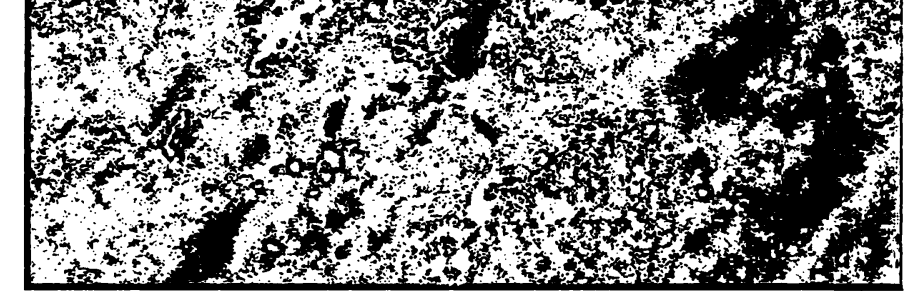

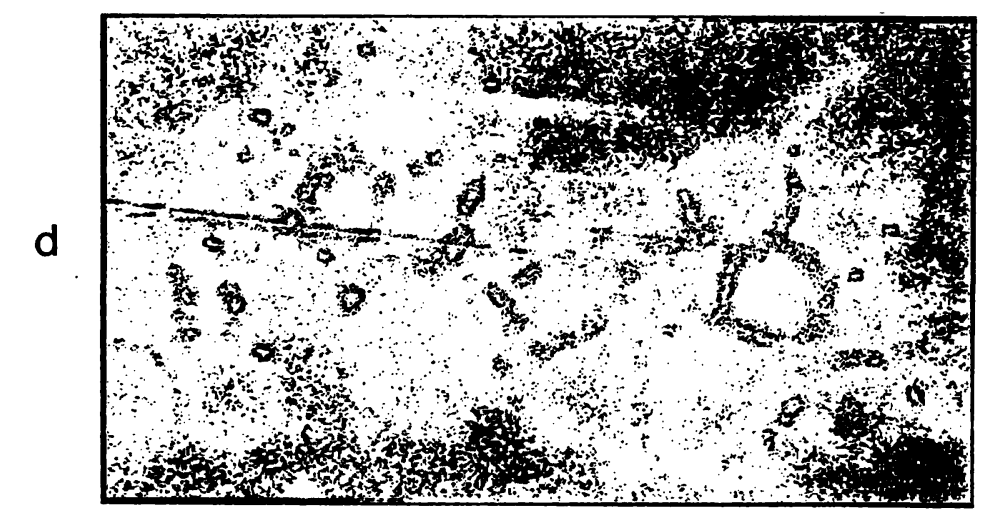

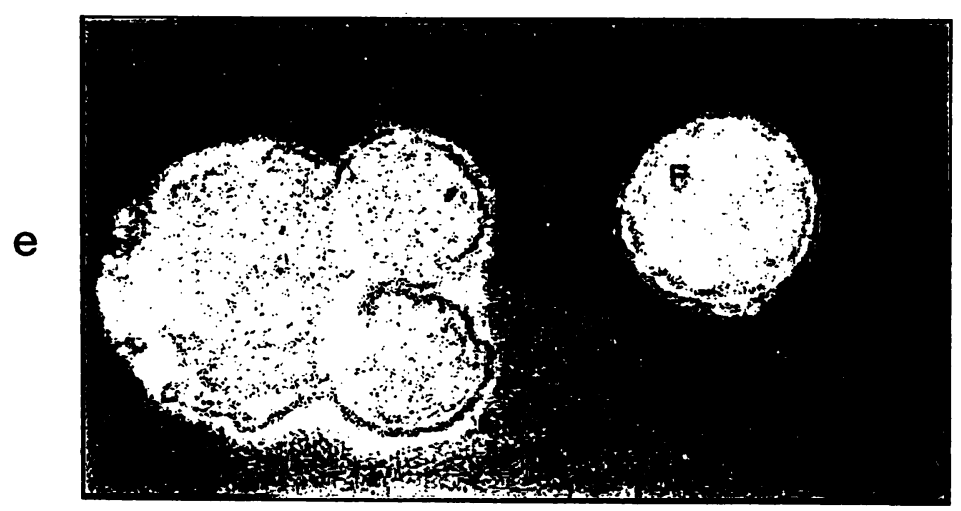

Fig. 4. 
of BISL-32, but none of them reacted with the same epitopes as did BISL-32. Antibodies 521F2, 673D2 and 673D5 stained structures, which were identified as B-cells by the use of an antihuman-insulin serum from guinea pig (fig. $3 \mathrm{~b}$ and $4 \mathrm{~b}$ ). When serial sections from the same pancreas were incubated with different monoclonal antibodies, it became evident that different substructures or cells were reactive as demonstrated for MAB $794 \mathrm{~A} 2$ and $866 \mathrm{~A} 6$ in figure $3 \mathrm{c}$ and $4 \mathrm{c}$.

By use of radioimmunological (RIA) and enzymeimmunological (ELISA) methods the clones were tested for reactivity with defined human polypeptides and structural proteins (tab. 2). None of the monoclonal antibodies was able to bind proinsulin, insulin, C-peptide, glucagon or somatostatin. Binding was also negative with thyroglobulin and the endocrinespecific isoenzyme $\gamma$-enolase. Monoclonal antibodies 673D2 and D5, 866A6 and 1163B1 gave a low signal within the heparan sulphate ELISA, while all other proteins listed in table 2 were negative.

Cross-reactivity of the selected seven monoclonal antibodies on various tissues and cell lines is listed in table 3. All of our monoclonal antibodies were reactive on islets from normal human pancreas as well as on cryostat sections from three different nesidioblastosis pancreata, except antibody 1163B1 which was unreactive on the second nesidioblastosis tissue.

No reaction was observed on sections from human thyroid, liver, skeletal muscle or two breast cancer specimens. Monoclonal antibodies 303F1 and 866A6 (fig. $3 \mathrm{e}$ ) were reactive on porcine and bovine pancreas, 673D2, D5 and 794A2 only on bovine pancreas. Reactivity within the RIN-cell ELISA of the clones $303 \mathrm{~F} 1$, 673D2, D5 and 866A6 was also reflected in the indirect immunofluorescence with adherent and floating RIN-cells. Monoclonal antibody $303 \mathrm{~F} 1$ gave rim fluorescence on normal pancreas sections (fig. $3 \mathrm{~d}$ ) as well as on floating RIN-cells (fig. 4 d). Obviously, reactivity on RIN cells was accompanied by reactivity on cryostat sections from a solid neuroblastoma as well as by membrane staining of adherent neuroblastoma cells (line SK-N-SH). All other cell lines tested and listed in table 3 were negative, except the epidermoid carcinoma cell line A431, which was strongly stained by monoclonal antibody 1163B1 (fig. 4e).

Western blot experiments were carried out with nesidioblastosis tissue 3. Monoclonal antibodies 673D5 (not shown), 303F1, 521F2 and some hybrids gave no detectable bands. Small bands were found for

Fig. $3 \mathrm{a}-\mathrm{e}$.

a) Immunofluorescence on human nesidioblastosis pancreas (case 3) double fluorescence procedure with MAB 1163B1 and FITC-labelled antimouse immunoglobulin (indirect immunofluorescence)

b) Immunofluorescence on human nesidioblastosis pancreas (case 2) double fluorescence procedure with MAB 673D5 and TRITC-labelled antimouse immunoglobulin (indirect immunofluorescence)

c) Serial sections $(3 \mathrm{c} ; 4 \mathrm{c})$ from normal human pancreas MAB 794A2; FITC labelled antimouse immunoglobulin (indirect immunofluorescence) $\times 170$

d) Immunofluorescence on normal buman pancreas

MAB 303F1; FITC-labelled antimouse immunoglobulin (indirect immunofluorescence)

e) Immunofluorescence on bovine pancreas $\times 420$ MAB 866A6; FITCC-labelled antimouse immunoglobulin (indirect immunofluorescence) $\times 170$

Fig. 4 a $-e$.

a) Same cryostat section as in 3 a

TRITC-labelled MAB BIS̈L-32 (direct immunofluorescence) $\quad \times 170$

b) same cryostat section as in $3 \mathrm{~b}$

FITC-labelled anti-insulin serum from guinea pig (indirect immunofluorescence)

c) Serial section (3c; 4c) from normal human pancreas

MAB 866A6; FITC-labelled antimouse immunoglobulin (indirect immunofluorescence)

d) Immunofluorescence on floating RIN m5F cells $\times 170$

MAB 303F1; FITC-labelled antimouse immunoglobulin (indirect immunofluorescence)

e) Immunofluorescence on floating A431 cells $\times 580$

MAB 1163B1; FITC-labelled antimouse immunoglobulin (indirect immunofluorescence) 
Tab. 2. Reactivity of monoclonal islet cell antibodies with defined polypeptides

\begin{tabular}{|c|c|c|c|c|c|c|c|c|}
\hline \multirow[t]{2}{*}{ Polypeptide } & \multirow{2}{*}{$\begin{array}{l}\text { Assay } \\
\text { type }\end{array}$} & \multicolumn{7}{|l|}{ Clones } \\
\hline & & $303 F 1$ & $521 \mathrm{~F} 2$ & 673D2 & 673D5 & $794 \mathrm{A2}$ & $866 \mathrm{A6}$ & 1163B1 \\
\hline Human insulin & RIA & - & - & - & - & - & - & - \\
\hline proinsulin & RIA & - & - & - & - & $=$ & $\dot{4}$ & - \\
\hline C-peptide & RIA & - & - & - & - & - & - & - \\
\hline glucagon & RIA & - & - & - & - & - & - & - \\
\hline somatostatin & RIA & - & - & - & - & - & $=$ & $\div$ \\
\hline Thyroglobulin & RIA & - & - & - & - & - & - & - \\
\hline$\gamma$-Enolase & RIA & - & - & $=$ & - & - & - & - \\
\hline Heparan sulphate & ELISA & - & - & $(+)$ & $(+)$ & - & - & + \\
\hline Laminin & ELISA & - & n.d. & n.d. & - & - & - & - \\
\hline Fibronectin & ELISA & n.d. & n.d. & - & - & n.d. & - & - \\
\hline Actin & ELISA & - & - & - & - & - & - & - \\
\hline Human serum albumin & ELISA & - & - & - & - & - & - & - \\
\hline Bovine serum albumin & ELISA & - & - & - & - & - & - & - \\
\hline $\begin{array}{l}\text { Insulin receptor } \\
\text { (placenta) }\end{array}$ & $\begin{array}{l}\text { Western } \\
\text { blot }\end{array}$ & - & - & - & - & - & - & - \\
\hline
\end{tabular}

n. d. $=$ not determined

Tab. 3. Reactivity of monoclonal islet cell antibodies with various tissues and cell types

\begin{tabular}{|c|c|c|c|c|c|c|c|c|}
\hline \multirow{3}{*}{$\begin{array}{l}\text { Species of } \\
\text { origin }\end{array}$} & \multirow[t]{3}{*}{ Tissue/cell type } & \multicolumn{7}{|c|}{ Immunohistochemistry } \\
\hline & & \multicolumn{7}{|l|}{ clones } \\
\hline & & $303 \mathrm{~F} 1$ & $521 \mathrm{~F} 2$ & $673 \mathrm{D} 2$ & $673 \mathrm{D} 5$ & $794 \mathrm{~A} 2$ & $866 A 6$ & $1163 \mathrm{~B} 1$ \\
\hline \multirow[t]{11}{*}{ Human } & Normal pancreas & + & + & + & + & + & + & + \\
\hline & Nesidioblastosis 1 & + & + & + & + & + & + & + \\
\hline & Nesidioblastosis 2 & + & + & + & + & + & + & - \\
\hline & Nesidioblastosis 3 & + & n.d. & n. d. & + & + & + & + \\
\hline & Thyroid & - & - & - & - & - & - & - \\
\hline & Liver & - & - & - & - & - & - & - \\
\hline & Muscle & - & - & - & - & - & - & - \\
\hline & Breast cancer 1 & - & - & - & - & - & - & - \\
\hline & Breast cancer 2 & - & - & - & - & - & - & - \\
\hline & Neuroblastoma & + & - & + & + & - & + & - \\
\hline & Glucagonoma & + & - & n.d. & n.d. & - & - & - \\
\hline Bovine & pancreas & + & - & + & + & + & + & - \\
\hline Porcine & pancreas & + & - & - & - & - & + & - \\
\hline \multicolumn{9}{|c|}{ Cell line } \\
\hline \multirow{3}{*}{\multicolumn{2}{|c|}{$\begin{array}{l}\text { ELISA } \\
\text { viable adherent cells } \\
\text { viable floating cells }\end{array}$}} & + & - & + & + & - & + & $(t)$ \\
\hline & & + & - & + & + & - & + & + \\
\hline & & + & - & + & + & - & + & - \\
\hline \multicolumn{9}{|c|}{ Epidermoid carcinoma A431 } \\
\hline \multirow{2}{*}{\multicolumn{2}{|c|}{$\begin{array}{l}\text { adherent cells } \\
\text { floating cells }\end{array}$}} & - & - & - & - & - & - & + \\
\hline & & - & - & - & - & - & - & + \\
\hline \multicolumn{9}{|c|}{ Neuroblastoma IMR 32} \\
\hline \multicolumn{2}{|c|}{$\begin{array}{l}\text { adherent cells } \\
\text { floating cells }\end{array}$} & - & - & - & - & - & - & - \\
\hline \multicolumn{9}{|c|}{ Neuroblastoma SK-N-SH } \\
\hline adheren & & + & - & + & + & - & + & + \\
\hline floating & & - & - & - & - & - & - & - \\
\hline \multicolumn{9}{|c|}{ Breast cancer MCF7 } \\
\hline \multicolumn{2}{|c|}{$\begin{array}{l}\text { adherent cells } \\
\text { floating cells }\end{array}$} & - & - & - & - & - & - & - \\
\hline \multicolumn{9}{|c|}{ Breast cancer MDA 231} \\
\hline \multirow{2}{*}{\multicolumn{2}{|c|}{$\begin{array}{l}\text { adherent cells } \\
\text { floating cells }\end{array}$}} & - & - & - & - & - & - & - \\
\hline & & - & - & - & - & - & - & - \\
\hline \multicolumn{9}{|c|}{ Human fibroblasts } \\
\hline adheren & cells & n. d. & n.d. & $\cdot-$ & - & - & - & - \\
\hline
\end{tabular}




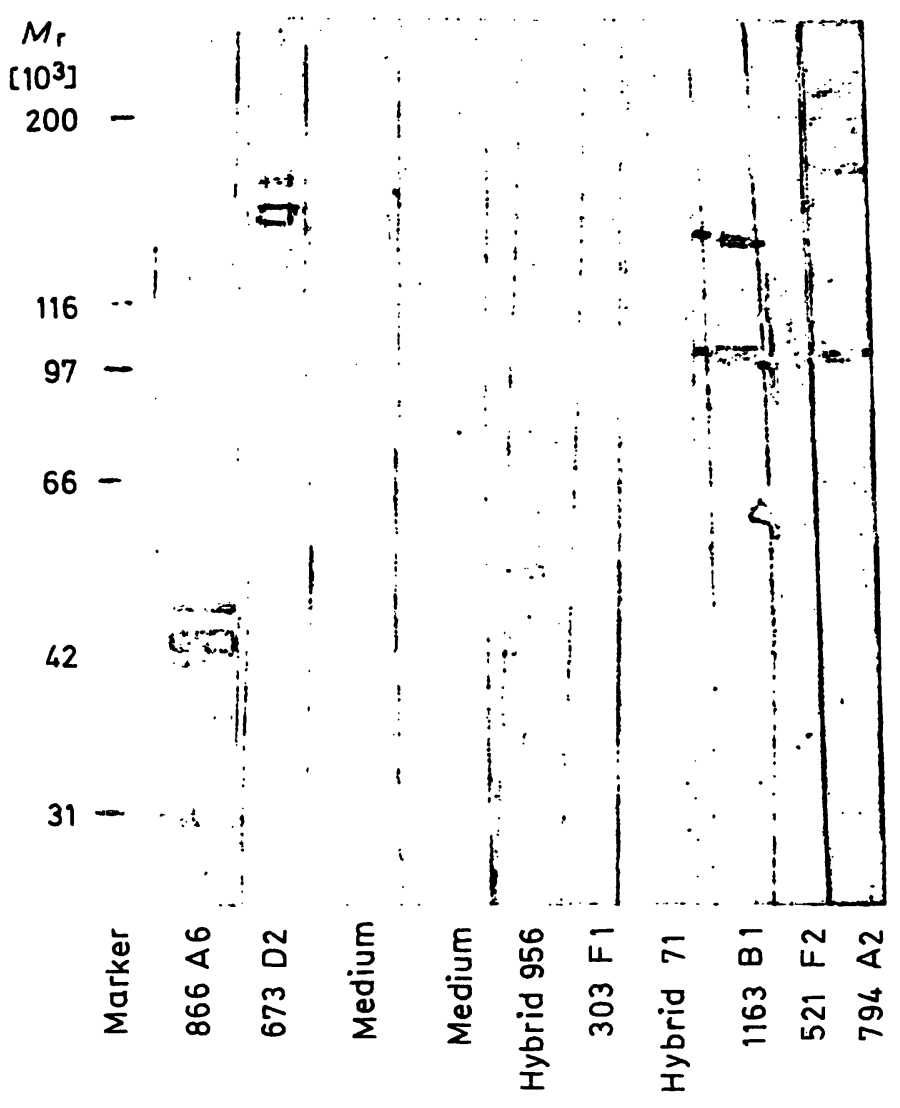

Fig. 5. Western blot procedure with detergent extracts from nesidioblastosis pancreas (case 3 )

Marker: myosin, $M_{\mathrm{r}} 200 \times 10^{3} ; \beta$-galactosidase, $M_{\mathrm{r}} 116$ $\times 10^{3}$; phosphorylase b, $M_{\mathrm{r}} 97 \times 10^{3}$; bovine serum albumin, $M_{\mathrm{r}} 66 \times 10^{3}$.

673D2 $\left(M_{\mathrm{r}} 140-150 \times 10^{3}\right), 1163 \mathrm{~B} 1\left(M_{\mathrm{r}} 97 ; 125\right.$ $\left.\times 10^{3}\right), 794 \mathrm{~A} 2\left(M_{\mathrm{r}} 97 ; 150 ; 200 \times 10^{3}\right)$, while monoclonal antibody 866 A6 recognized three distinguished bands in the range from $M_{\mathrm{r}} 40$ to $45 \times 10^{3}$.

\section{Discussion}

Nesidioblastosis is a rare disease of infants and is characterized by augmentation of the pancreatic islets of Langerhans or single islet cells as a result of continuous formation of new islet cells from the duct epithelium $(7,8)$. In most cases the total mass of all the different cell types of the islets is increased threeto ten fold. Due to the hyperinsulinism the disease is clinically characterized by severe hypoglycaemic attacks. Total pancreatectomy is therefore the therapeutic method of choice. In contrast to solid insulinomas, which in most cases secrete insulin autonomously, nesidioblastosis tissue remains mostly sensitive to specific stimuli such as glucose, leucine or others (9). Thus the functional apparatus of the nesidioblastosis islets seems to be relatively intact. Furthermore, diabetic sera reactive with normal islets were also positive on nesidioblastosis pancreas, whereas some of the insulinomas we have tested did not react with diabetic autoantibodies. Therefore nesidioblastosis tissue seems to be the ideal source for preparation of human islets. The proliferative power of the isolated nesidioblastosis islets remained demonstrable in cell culture up to several months (10). The tissues (normal pancreas and nesidioblastosis 2) used in this study for immunofluorescence were from two donors with blood group 0 , thus there was no interference with the blood group system.

Various immunologic phenomena are usually demonstrable at onset of type I diabetes, among them the presence of autoantibodies against cytoplasmic as well as membrane structures of the B-cells of islets. If the immune response is in fact responsible for the damage of the B-cells in type I diabetes, it seems probable that membrane structures serve as self antigens in combination with expressed HLA-molecules. We therefore used the membrane fraction of the nesidioblastosis islet cells as immunogen in $\mathrm{BALB} / \mathrm{c}$ mice for induction of specific lymphocytes. Fusion and selection of the antibody secreting hybrids resulted in at least 7 clones with different specificity. Antibody $521 \mathrm{~F} 2$ was only reactive on human pancreas slices, while most of the others were also positive on bovine and/or porcine pancreas. Cross-reactivity with different cells and tissues from various species seems to be mainly a function of the screening methods used for selection of positive clones. As already mentioned by Garzelli et al. (11), one of the major hurdles in isolating monoclonal islet antibodies is the time and skill required to screen hundreds of hybrids for reactivity on tissue slices by immunofluorescence. Since viable human islet cells are usually not available, most investigators use the rat insulinoma cell line RIN m 5F for screening of the respective hybrids $(11-14)$. This method selects clones without species specificity and it seems further that these selected clones are not specific for islet cells, but react also with other endocrine tissues. RIN-cell positive antibodies 303F1, 673D2, D5 and 866A6 reacted also with bovine pancreas, a solid neuroblastoma and the neuroblastoma cell line SK-N-SH. None of the seven clones stained any structures on human thyroid. Thus it seems clear that some of our monoclonal antibodies recognize common epitopes or antigenic determinants on different normal tissues and malignant tumours. This is in line with reports in the literature about murine monoclonal islet cell antibodies (15) as well as human monoclonal antibodies derived from Ebstein-Barr virus-transformed lymphocytes from diabetics $(11,16)$. However at least two of our monoclonal antibodies, 521F2 and 794A2, seem to be islet cell-specific, although the latter stained undefined structures on bovine pancreas. 
All of the antibodies reacting with the neuroblastoma

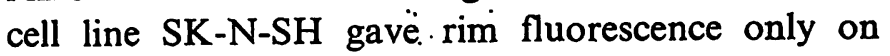
viable adherent cells grown on cover slips. They did not react with floating cells. A possible explanation for this discrepancy is the fact that the adherent growing cells were harvested by mild trypsination, a procedure, which might have destroyed antigenic peptide structures on the cell surface. This explanation was confirmed by the Western blot experiments. Protein antigens were recognized only by those antibodies reactive with adherent SK-N-SH-cells, but unreactive with floating cells. Some of our monoclonal antibodies did not recognize proteins using the Western blot procedure. This fact probably reflected findings on the carbohydrate or glycolipid nature of specific antigens published by Eisenbarth's group in a series of papers $(12-15)$. Experiments on the possible nonpeptide nature of the antigens, against which our monoclonal antibodies are directed, are in progress. Why 24 of our initial hybrids reacted only in the RINcell ELISA, but not on human cryostat sections remains unclear. These hybrids were excluded from further cloning.

Up to now there is no clear evidence that monoclonal antibodies prepared by hybridoma technology or $E b$ stein-Barr-virus transformation recognize the same structures on human islet cells as do diabetic autoantibodies. Nonetheless, islet cell-specific monoclonal antibodies are providing an approach for identification of antigenic determinants common to all endocrine cells and those specific for human islet $\bar{B}$-cells. This may help to answer the question, of why type I diabetes is in fact characterized by a selective destruction of the B-cells, although the patients have antibodies in their serum against a variety of other endocrine organs.

\section{References}

1. Lacy, P. E. \& Kostianovsky, M. (1967) Diabetes 16, 35-39.

2. Galfrey, M. \& Milstein, C. (1981) Meth. Enzymol. 73, 3.

3. Köhler, G. \& Milstein, C. (1975) Nature 256, 495-498.

4. Hübner, G., Gokel, J. M., Pongratz, D., Johannes, A. \& Park, J. W. (1986) Virchows Arch. (Pathol. Anat.) 408, $611-621$.

5. Gazdar, A., Chick, W., Oie, H., Sims, H., King, H., Weir, G. \& Lauris, V. (1980) Proc. Natl. Acad. Sci. USA 77, 3519-3523.

6. Srikanta, S., Telen, M., Posillico, J. T., Dolinar, R., Krisch, K., Haynes, B. F. \& Eisenbarth, G. S. (1987) Endocrinology $120,2240-2244$.

7. Köppel, G. \& Seifert, G. (1975) Dtsch. Med. Wochenschr. $100,1906-1910$.

8. Soltész, G. \& Aynsley-Green, A. (1984) In: Advances in Int. Med. and Ped. pp. 152-202. Springer, Berlin, Heidelberg, New York, Tokyo.

9. Köppel, G., Altenähr, E., Reichel, W., Willig, R. \& Freytag, G. (1974) Diabetologia 10, 245-252.

10. Gerbitz, K.-D. \& Boenke, B. unpublished observations.

11. Garzelli, C., Taub, F. E., Jenkins, M. C., Dreh, D. W., Ginsberg-Fellner, F. \& Notkins, A. L. (1986) J. Clin. Invest. $77,1627=1631$.

12. Eisenbarth, G. S., Shimizu, K., Bowring, M. A. \& Well, S. (1982) Proc. Natl. Acad. Sci. USA 79, 5066-507.0.

13. Crump, M. A., Scearce, R., Dobersen, M., Kortz, W. \& Eisenbarth, G. S. (1982) J. Clin. Invest. 70, 659-666.

14. Powers, A. C., Rabizadeh, A., Akerson, R. \& Eisenbarth, G. S. (1984) Endocrinology 114, 1338-1343.

15. Srikanta, S., Krisch, K. \& Eisenbarth, G. S. (1986) Diabetes 35, 300-305.

16. Casali, P., Inghirami, G., Nakamura, M., Davies, T. F. \& Notkins, A. L. (1986) Science 234, 476-479.

17. Gerbitz, K.-D., Haslberger, K., Schleicher, E. \& Haslbeck, M. (1986) Fresenius Z. Anal. Chem. 324, 292-293.

Prof. Dr. Klaus-D. Gerbitz

Inst. f. Klin. Chemie

Krankenhaus Schwabing

Kölner Platz 1

D-8000 München 40 
WAKO-30R. Stands for realization of the newest technologies into a practice-oriented analyzer to assure optimum benefit for the user.

WAKO-3OR. Stands for quick results in emergency medicine. Easiest operation assures perfect runs.

WAKO-30R. Stands for profitability by minimizing reagent comsumption.

WAKO-3OR. Stands for efficient operation from starting testing to storage and documentation of test results.

WAKO-30R. Stands for maximum performance with minimum expenditure.
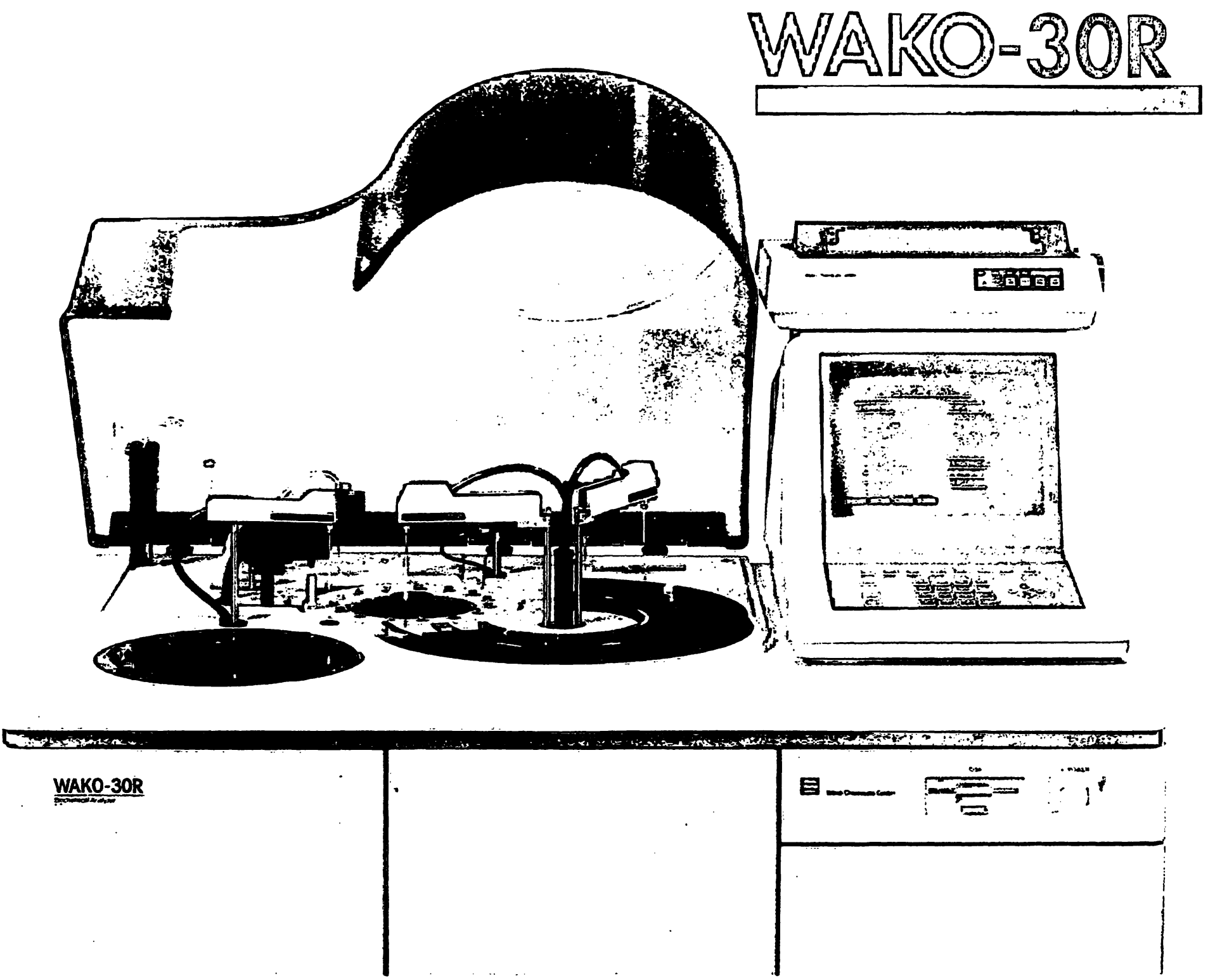

Please ask for further informations:

WAKO CHEMICALS GMBH, Nissanstraße 2, D-4040 Neuss 1, Germany-West, Phone 02101/35011, Telex 8517001, Facsimile $02101 / 39879$ WAKO PURE CHEMICAL INDUSTRIES, LTD., 10 Doshomachi 3-Chome. Higashi-Ku., Osaka, 541 Japan, Phone (06) 203-3741, Telex 0522-9113-4 WAKOOS J, Facsimile (06) 222-1203 


\section{Willhelm Friedrich}

\section{Vitamins}

1988. $17 \mathrm{~cm} \times 24 \mathrm{~cm}$. XII, 1062 pages. Hardcover. DM 380,-; approx. US $\$ 225.00$ ISBN 3110101447

A comprehensive, authoritative Handbook and reference source of all aspects of vitamins.

The book at a glance

$\odot$ Complete and systematic overview of all water- and fat-soluble vitamins

- Introductory chapter presenting basic general information on the vitamins

- Numerous illustrations, formulas, tables, etc.

- Comprehensive and up-to-date bibliographic references at the end of each chapter

- Supplementary bibliography of publications that appeared subsequent to completion of the editorial work on the book

\section{From the Contents}

Introduction - Vitamin A and its Provitamins - Vitamin D - Vitamin E - Vitamin K . Thiamin (Vitamin $\mathrm{B}_{1}$, Aneurin) - Vitamin $\mathrm{B}_{2}$ : Riboflavin and its Bioactive Variants · Niacin: Nicotinic Acid, Nicotinamide, NAD (P) $\cdot$ Vitamin $B_{6} \cdot$ Folic Acid and Unconjugated Pteridines - Biotin · Pantothenic Acid - Vitamin $B_{12} \cdot$ Vitamin C . Literature Supplement $\cdot$ Subject Index

\section{Potential audience}

Biochemists, Biologists, Clinicians, Pharmacologists, Toxicologists, Physiologists, Pharmacists, Nutritionists, Organic and Analytical Chemists. Institutes, Libraries 